\title{
Inheritance of a long juvenile period under short-day conditions in soybean
}

\author{
Valéria Carpentieri-Pípolo ${ }^{1}$, Leones Alves de Almeida ${ }^{2}$ and Romeu Afonso de S. Kiihl ${ }^{2}$ \\ ${ }^{1}$ Departamento de Agronomia, Universidade Estadual de Londrina-Londrina, PR, Brazil. \\ ${ }^{2}$ Embrapa-Soja, Londrina, PR, Brazil.
}

\begin{abstract}
The long juvenile period (LJP) characteristic of soybean (Glycine max L. Merrill) cultivars delays flowering under short-day conditions. This trait may be important in increasing the adaptation range of soybean to low latitudes and provides greater flexibility for sowing times within the same latitude. The inheritance of the long juvenile period was studied in the MG/BR22 (Garimpo) soybean cultivar to provide knowledge to support the development of cultivars adapted to short day conditions. Four cultivars ('Paraná', 'Bossier', 'Bragg', and 'Davis') were crossed among each other and with MG/BR 22 ('Garimpo'). The study was conducted under short-day conditions (early sowing) in a greenhouse and in the field, in Londrina, Paraná, $\left(23^{\circ} 22^{\prime}\right.$ south latitude). The parents and the $F_{1}, F_{2}$, and $F_{3}$ populations were assessed daily for flowering. The genotype ratios of 15:1 $\left(p>0.95, \chi^{2}\right.$ test) and 8:7:1 $(p=0.193)$ for the $F_{2}$ and $F_{3}$ generations, respectively, obtained for the Paraná $x$ Bossier cross indicated a case of digenic interaction with a duplicate recessive epistatic effect for the LJP character. Segregation of the $F_{2}$ population from the MG/BR 22 (Garimpo) x Paraná cross resulted in the expected ratio of 3:1 $(p=0.166$, indicating that the MG/BR 22 (Garimpo) and Paraná cultivars differed at a single locus. Similarly, in the MG/BR 22 (Garimpo) x Bossier cross, a 3:1 $(p=0.065)$ segregation indicated that these two cultivars differed at a single locus for number of days to flowering. The Davis cultivar had the same gene for LJP as the Paraná cultivar (aa). The $F_{2}$ segregation of the classic flowering Bragg with MG/BR 22 (Garimpo) cross resulted in a 15:1 $(p=0.138$ ) ratio, indicating that these two cultivars differed at two loci for flowering. The genotypes assigned to the cultivars were aaBB for Paraná, $A A b b$ for Bossier and aabb for MG/BR 22 (Garimpo). A single locus in recessive homozygosis does not produce LJP.
\end{abstract}

Key words: long juvenile period, soybean, Glycine max, delayed flowering, short-days.

Received: November 26, 1999; accepted: September 24, 2002.

\section{Introduction}

Soybean, a short-day plant, originated in China between latitudes $30^{\circ}$ and $45^{\circ}$ north. Cultivation of this plant under short-day conditions, out of season, or at low latitudes, results in cultivars with a characteristic response to an altered photoperiod, namely, early flowering, low plant height, and low grain yield.

Until the end of the 1960s, commercial cultivation of soybean was limited by photoperiod barriers, which restricted this species to latitudes above $22^{\circ}$. In Brazil, soybean cultivation was restricted to the southern part of the country for a long time because of dependence on cultivars introduced from the United States. The photoperiod barrier was overcome at the end of the 1970s with the introduction of the long juvenile period (LJP) trait. Mechanized soybean cultivation could finally be conducted in regions with less than $15^{\circ}$ latitude (Neumaier and James, 1993).

Send correspondence to Valéria Carpentieri-Pípolo. Universidade Estadual de Londrina, Caixa Postal 6001, 86051-990 Londrina, PR, Brazil. E-mail: pipolo@uel.br.
Soybean breeding programs for lower latitudes were the starting point for subsequent commercial soybean cultivation in the 'fallow' season (dry season or winter). Currently, if temperatures are not too low and if there is adequate irrigation, soybean cultivation is possible in the savannah region of Brazil in the fallow season (Spehar et al. 1993). Brazil pioneered soybean cultivation at latitudes less than $20^{\circ}$. The contribution of the central western region and of the state of Bahia to the total cultivated area increased from $5.5 \%$ in the $1973 / 74$ season to $39.0 \%$ in the $1992 / 93$ season. The contribution of this region in the total production increased from $5.1 \%$ to $40.0 \%$ in 19 years (Roessing and Guedes, 1993).

A greater knowledge of the genetic mechanisms controlling LJP would assist in developing soybean genotypes with a wider range of sowing dates suitable for lower latitudes. Genetic control of flowering and maturity time in soybeans under short-day conditions is controlled by recessive alleles (Kiihl, 1976; Hartwig and Kiihl, 1979; Tisselli Jr, 1981; Toledo and Kiihl, 1982 ab; Carpentieri-Pípolo, 2000). We examined the inheritance of LJP conditioned by 
the complementary effects of gene recombination among cultivars with classic flowering in order to screen for genetic variability that would be useful for developing cultivars adapted to different regions of Brazil.

\section{Material and Methods}

Ten $F_{2}$ populations developed from crosses between conventional juvenile types ('Paraná', 'Bossier', 'Davis', and 'Bragg') and the LJP carrier MG/BR-22 (Garimpo) (Table I) were obtained. The crosses included the diallel crosses between the four conventional juvenile types and the crosses of each of the four conventional juvenile types and the LJP carrier MG/BR-22 (Garimpo) (Table II). The $\mathrm{F}_{1}, \mathrm{~F}_{2}$, and $\mathrm{F}_{3}$ generations, including some reciprocals, were evaluated. The study was conducted from December 1992 to March 1995, on the experimental station at the Embrapa Soybean National Research Center, Londrina, in the state of Paraná (2322' south latitude), Brazil.

The genotypes were sown in a greenhouse at seven day intervals from November 1992 to March 1993 to allow hybridization (through concomitant flowering) and hand pollinated among cultivars with different cycles. The $\mathrm{F}_{1}$ plants were grown in a greenhouse in the winter of 1993 to obtain seeds for the $\mathrm{F}_{2}$ population. The plants received additional artificial incandescent and fluorescent light $6 \mathrm{~h}$ per day for 26 days after emergence. The seeds collected from the $F_{1}$ plants $\left(F_{2}\right.$ seeds) were divided into three samples. One sample was assessed in the 93/94 season in a greenhouse (Experiment I), the second sample was assessed in the field in the 93/94 season (Experiment II), and the third sample was kept in a cold room and assessed in the 94/95 season (Experiment III).

The $\mathrm{F}_{2}$ population of each cross in experiment I was sown in 15 vases with seven seeds each. Two pots with each parent and one vase with the $F_{1}$ population were sown for each treatment. The parents and their $F_{1}$ and $F_{2}$ generations were assessed daily for flowering. The flowering date was recorded when the first flower opened on the plant.

In Experiment II, the parents and $\mathrm{F}_{2}$ populations were sown in the field on September 29, 1993, which is earlier than the normal sowing date, to provide short-day condi- tions. Four 5-m rows with 10 seeds/m were sown for each cross. Row spacing was $0.50-\mathrm{m}$. A single $5-\mathrm{m}$ row was sown for each parent. Flowering was assessed daily on all the plants in the plot. The date of flowering was recorded for individual plants as the first day an open flower appeared on the plant.

The $F_{2}$ population was assessed in Experiment III to complement the $F_{2}$ segregation data obtained in the 93/94 season. The remnant seeds from the 92/93 season which had been kept in cold storage were used. Each cross was sown in 7.5-m rows with four replications and each parent was sown in a single $7.5-\mathrm{m}$ row with four replications.

The $F_{3}$ population was sown in $2-m$ rows with 10 seeds $/ \mathrm{m}$ spaced 0.5 apart; the seeds in each row came from a single $\mathrm{F}_{2}$ plant. Each parent was sown in 2-m rows with $10 \mathrm{seeds} / \mathrm{m}$. Flowering was assessed daily after the opening of the first flower. In all experiments, plants were classified as early flowering plants (conventional-juvenile) (CJ) or late flowering (LJP) by comparing the flowering date distribution of the respective early flowering plants and LJP parental lines. The dates were categorized and flowering categories established using the narrow flowering range of the parents. Long Juvenile Period (LJP) was considered when the genotypes showed more than $46 \mathrm{~d}$ to flowering. A chi-square test for the distribution of plant frequencies versus the days to flowering characteristic was used to check the genetic hypotheses of monogenic, digenic, and polygenic inheritance (Snedecor and Cochran, 1980).

\section{Results and Discussion}

The temperatures during Experiment I (greenhouse) varied from $16.5^{\circ} \mathrm{C}$ to $34.3^{\circ} \mathrm{C}$ and in Experiment II (field) from $14.3{ }^{\circ} \mathrm{C}$ to $27.1{ }^{\circ} \mathrm{C}$. A significant shortening in the number of days to flowering was observed in the plants in Experiment I, compared to those of Experiments II and III (Tables I and II). The populations and cultivars in Experiments I and II were sown at the same time, but in Experiment I (greenhouse), the temperature, particularly at night, was relatively higher than in the field. The main cause of early flowering may thus be temperature. The influence of

Table I - Means, standard deviation (SD), and range of the number of days to flowering of the soybean parent cultivars in experiments under short-day conditions.

\begin{tabular}{|c|c|c|c|c|c|c|c|c|c|c|}
\hline \multirow[b]{2}{*}{ Genotypes } & \multirow[b]{2}{*}{ Loci* } & \multicolumn{3}{|c|}{ Experiment I } & \multicolumn{3}{|c|}{ Experiment II } & \multicolumn{3}{|c|}{ Experiment III } \\
\hline & & Mean \pm SD & $\mathrm{CV} \%$ & Range & Mean \pm SD & $\mathrm{CV} \%$ & Range & Mean \pm SD & $\mathrm{CV} \%$ & Range \\
\hline Paraná & $a a$ & $27.3 \pm 1.5$ & 0.05 & $25-29$ & $36.3 \pm 1.0$ & 2.75 & $35-38$ & $38.4 \pm 2.4$ & 6.25 & $36-42$ \\
\hline Bossier & $b b$ & $33.1 \pm 1.1$ & 0.03 & $32-36$ & $39.9 \pm 2.1$ & 5.26 & $35-43$ & $43.9 \pm 2.5$ & 5.69 & $40-47$ \\
\hline Bragg & - & $24.8 \pm 0.8$ & 3.22 & $24-26$ & $28.1 \pm 0.7$ & 2.49 & $27-29$ & $30.5 \pm 2.3$ & 7.59 & $28-33$ \\
\hline Davis & $a a$ & $29.1 \pm 0.6$ & 2.06 & $28-30$ & $37.9 \pm 0.8$ & 2.11 & $36-39$ & $40.6 \pm 3.6$ & 8.87 & $33-47$ \\
\hline MG/BR-22 (Garimpo) & $a a b b$ & $35.9 \pm 1.5$ & 4.18 & $34-38$ & $51.4 \pm 2.0$ & 3.89 & $47-54$ & $53.6 \pm 2.2$ & 4.10 & $51-56$ \\
\hline
\end{tabular}

*Loci segregation. $\mathrm{CV} \%$ (Coeficient of Variation) $=\mathrm{SD} /$ Mean. 
Table II - Means, standard deviation (SD), and range of number of days to flowering of $F_{1}$ and $F_{2}$ soybean populations in three experiments under short-day conditions.

\begin{tabular}{|c|c|c|c|c|c|c|c|c|c|c|c|}
\hline \multirow[b]{2}{*}{ Cross } & \multirow[b]{2}{*}{ Loci* } & \multirow[b]{2}{*}{ Generation } & \multicolumn{3}{|c|}{ Experiment I } & \multicolumn{3}{|c|}{ Experiment II } & \multicolumn{3}{|c|}{ Experiment III } \\
\hline & & & $\begin{array}{c}\text { Mean } \pm \\
\text { SD }\end{array}$ & $\mathrm{CV} \%$ & Range & Mean \pm SD & $\mathrm{CV} \%$ & Range & Mean \pm SD & $\mathrm{CV} \%$ & Range \\
\hline $\begin{array}{l}\text { 1-Paraná x } \\
\text { Bossier }\end{array}$ & $\mathrm{AB}$ & $\begin{array}{l}F_{1} \\
F_{2}\end{array}$ & $\begin{array}{l}27.5 \pm 1.1 \\
28.6 \pm 3.0\end{array}$ & $\begin{array}{r}4.0 \\
10.4\end{array}$ & $\begin{array}{l}26-29 \\
23-38\end{array}$ & $34.3 \pm 5.5$ & 16.0 & $27-47$ & $40.3 \pm 7.4$ & 18.4 & $30-61$ \\
\hline $\begin{array}{l}\text { 2- Paraná x } \\
\text { Bragg }\end{array}$ & $A$ & $\begin{array}{l}\mathrm{F}_{1} \\
\mathrm{~F}_{2}\end{array}$ & $\begin{array}{l}26.1 \pm 0.8 \\
26.1 \pm 1.4\end{array}$ & $\begin{array}{l}3.0 \\
5.4\end{array}$ & $\begin{array}{l}25-27 \\
23-32\end{array}$ & $30.5 \pm 2.7$ & 8.8 & $27-38$ & $35.8 \pm 5.9$ & 16.5 & $27-70$ \\
\hline $\begin{array}{l}\text { 3- Paraná x } \\
\text { Davis }\end{array}$ & - & $\begin{array}{l}F_{1} \\
F_{2}\end{array}$ & $\begin{array}{l}27.4 \pm 0.5 \\
28.5 \pm 1.2\end{array}$ & $\begin{array}{l}1.8 \\
4.2\end{array}$ & $\begin{array}{l}27-28 \\
26-31\end{array}$ & $36.7 \pm 1.9$ & 5.1 & $29-41$ & $41.3 \pm 4.2$ & 10.2 & $34-63$ \\
\hline $\begin{array}{l}\text { 4- Davis x } \\
\text { Bragg }\end{array}$ & $A$ & $\begin{array}{l}F_{1} \\
F_{2}\end{array}$ & $\begin{array}{l}25.4 \pm 0.7 \\
25.9 \pm 1.3\end{array}$ & $\begin{array}{l}2.7 \\
5.0\end{array}$ & $\begin{array}{l}24-26 \\
23-30\end{array}$ & $30.7 \pm 3.2$ & 10.4 & $27-40$ & $33.8 \pm 4.6$ & 13.6 & $28-51$ \\
\hline $\begin{array}{l}\text { 5- Bragg x } \\
\text { Bossier }\end{array}$ & B & $\begin{array}{l}F_{1} \\
F_{2}\end{array}$ & $\begin{array}{l}25.0 \pm 0.4 \\
27.2 \pm 3.7\end{array}$ & $\begin{array}{r}1.6 \\
13.6\end{array}$ & $\begin{array}{l}24-26 \\
23-38\end{array}$ & $30.7 \pm 5.3$ & 17.2 & $27-43$ & $36.5 \pm 7.4$ & 20.3 & $28-65$ \\
\hline $\begin{array}{l}\text { 6- Davis x } \\
\text { Bossier }\end{array}$ & $A B$ & $\begin{array}{l}F_{1} \\
F_{2}\end{array}$ & $\begin{array}{l}26.5 \pm 0.5 \\
28.8 \pm 3.7\end{array}$ & $\begin{array}{r}1.8 \\
12.8\end{array}$ & $\begin{array}{l}26-27 \\
23-41\end{array}$ & $35.1 \pm 5.9$ & 16.8 & $27-48$ & $40.8 \pm 8.0$ & 19.6 & $28-61$ \\
\hline $\begin{array}{l}\text { 7- MG/BR22 } \\
\text { x Paraná }\end{array}$ & $B$ & $\begin{array}{l}F_{1} \\
F_{2}\end{array}$ & $\begin{array}{l}27.4 \pm 0.8 \\
28.8 \pm 3.3\end{array}$ & $\begin{array}{r}2.9 \\
11.4\end{array}$ & $\begin{array}{l}27-29 \\
24-43\end{array}$ & $41.4 \pm 5.6$ & 13.5 & $34-59$ & $48.3 \pm 7.2$ & 14.9 & $37-68$ \\
\hline $\begin{array}{l}\text { 8- MG/BR-22 } \\
\text { x Bossier }\end{array}$ & $A$ & $\begin{array}{l}\mathrm{F}_{1} \\
\mathrm{~F}_{2}\end{array}$ & $\begin{array}{l}34.7 \pm 1.0 \\
34.4 \pm 1.8\end{array}$ & $\begin{array}{l}2.8 \\
5.2\end{array}$ & $\begin{array}{l}33-36 \\
30-40\end{array}$ & $42.4 \pm 2.2$ & 5.2 & $35-47$ & $51.3 \pm 7.5$ & 14.6 & $30-68$ \\
\hline $\begin{array}{l}\text { 9- MG/BR22 } \\
\text { x Bragg }\end{array}$ & $A B$ & $\begin{array}{l}F_{1} \\
F_{2}\end{array}$ & $\begin{array}{l}26.2 \pm 0.4 \\
27.6 \pm 2.8\end{array}$ & $\begin{array}{r}1.5 \\
10.1\end{array}$ & $\begin{array}{l}26-27 \\
24-37\end{array}$ & $35.7 \pm 6.0$ & 16.8 & $27-48$ & $40.1 \pm 7.4$ & 18.4 & $28-63$ \\
\hline $\begin{array}{l}\text { 10-MG/BR22 } \\
\text { x Davis }\end{array}$ & $B$ & $\begin{array}{l}F_{1} \\
F_{2}\end{array}$ & $\begin{array}{l}29.6 \pm 1.9 \\
31.7 \pm 3.4\end{array}$ & $\begin{array}{r}6.4 \\
10.7\end{array}$ & $\begin{array}{l}29-30 \\
27-42\end{array}$ & $39.3 \pm 2.5$ & 6.4 & $34-49$ & $45.9 \pm 6.7$ & 14.6 & $34-63$ \\
\hline
\end{tabular}

*Loci segregation. CV\% (Coeficient of Variation $)=\mathrm{SD} /$ Mean.

temperature on flowering in soybean has been reported by several authors. Higher night temperatures have a significant effect on the induction of flowering which occurs during the dark, and leads to earlier flowering (Easton, 1924; Parker and Bortwick, 1950; Major et al., 1975; Summerfield et al., 1975; Shibles et al., 1976; Oliveira, et al. 1999).

The flowering means, standard deviations, and ranges of $F_{1}$ and $F_{2}$ populations were analyzed in three experiments (Tables I and II). Transgressive segregation for early flowering was observed in the Paraná x Bossier cross. Dominance for early flowering was detected in the $\mathrm{F}_{1}$ generation. In studies on soybean flowering under short-day conditions, Kiihl (1976) and Hartwig and Kiihl (1979) showed that the LJP characteristic is recessive. In our three experiments, the $\mathrm{F}_{2}$ populations had a multimodal distribution, with a greater number of early plants. The proportions obtained fitted the theoretical 15:1 ratio (conventional flowering: LJP ratio) as confirmed by the chi-square test, with probability values of $\mathrm{p}=0.25, \mathrm{p}=0.99$, and $\mathrm{p}=0.975$ for Experiments I, II, and III, respectively (Table III). These results suggested the action of two genes with independent distribution in which normal flowering was determined by genotypes with at least one dominant allele and LJP occurred only when the genotype was double recessive homozygous for two loci. Thus, the LJP trait in this cross was conditioned by duplicate recessive epistasis (Ramalho et al., 1994).

$\mathrm{F}_{3}$ family segregation was assessed to confirm these results. The observed phenotypic ratio of 41:31:6 fitted the expected genotypic ratio of 8:7:1 proposed for the two loci which determine LJP in the Paraná x Bossier cross (Table IV). These results indicated that LJP has a digenic inheritance, with the LJP trait in this population conditioned by two double recessive genes. The existence of a gene for LJP in the Paraná cultivar was reported by Kiihl and Garcia (1989) and Miranda et al. (1990). However, this gene alone is not sufficient to cause an appreciable delay in flowering under short-day conditions.

Bonato and Vello (1999) studied the time for flowering and maturity in the cultivars Paranagoiana and SS-1 cultivars. They indicated that early flowering and maturity are controlled by a single dominant gene and the natural mutations that originated the cultivars Paranagoiana and SS-1 cultivars occur at the same locus of the cultivar Paraná cultivar. Results quite similar to these were obtained by Gilioli (1979), in four crosses, under photoperiods of $13 \mathrm{~h}$ $21 \mathrm{~min}$, and by Ray et al. (1995) in plantings with days with $13 \mathrm{~h} 10 \mathrm{~min}$ and $14 \mathrm{~h} 02 \mathrm{~min}$ of light where they concluded that the LJP characteristic in PI 159925 accesses was controlled by a pair of recessive alleles identified as $j j$ and Vargas (1996) in crosses involving the cultivars Doko, 
Table III - Observed and expected phenotypic ratios of number of days to flowering in the $\mathrm{F}_{2}$ populations.

\begin{tabular}{|c|c|c|c|c|c|c|c|c|c|}
\hline \multirow[t]{2}{*}{ Cross } & \multirow[t]{2}{*}{ Experiment } & \multirow[t]{2}{*}{$\mathrm{n}}$. & \multicolumn{2}{|c|}{$\mathrm{CJ}^{1}$} & \multicolumn{2}{|c|}{$\mathrm{LJ}^{2}$} & \multirow[t]{2}{*}{ Ratio } & \multirow[t]{2}{*}{ Chi-Square $\left(\chi^{2}\right)$} & \multirow[t]{2}{*}{ Probability } \\
\hline & & & Obs. & Exp. & Obs. & Exp. & & & \\
\hline 1- Paraná $\mathrm{x}$ & I & 361 & 342 & 338.4 & 19 & 22.6 & \multirow[t]{3}{*}{$15: 1$} & 0.6 & 0.454 \\
\hline \multirow[t]{2}{*}{ Bossier } & II & 182 & 171 & 170.6 & 11 & 11.4 & & 0.0 & 0.950 \\
\hline & III & 225 & 212 & 210.9 & 13 & 14.1 & & 0.1 & 0.760 \\
\hline \multirow{3}{*}{$\begin{array}{l}\text { 2- Parana x } \\
\text { Bragg }\end{array}$} & I & 407 & 296 & 305.3 & 111 & 101.8 & \multirow{3}{*}{$3: 1$} & 1.1 & 0.295 \\
\hline & II & 226 & 173 & 169.5 & 53 & 56.5 & & 0.3 & 0.603 \\
\hline & III & 366 & 261 & 274.5 & 105 & 91.5 & & 2.7 & 0.100 \\
\hline \multirow{3}{*}{$\begin{array}{l}\text { 4-Davis } \mathrm{x} \\
\text { Bragg }\end{array}$} & I & 366 & 268 & 274.5 & 98 & 91.5 & \multirow[t]{3}{*}{$3: 1$} & 0.6 & 0.454 \\
\hline & II & 235 & 173 & 176.3 & 62 & 58.8 & & 0.2 & 0.699 \\
\hline & III & 272 & 198 & 204 & 74 & 68 & & 0.8 & 0.388 \\
\hline \multirow{3}{*}{$\begin{array}{l}\text { 5-Bragg } x \\
\text { Bossier }\end{array}$} & I & 343 & 267 & 257.3 & 76 & 85.8 & \multirow[t]{3}{*}{$3: 1$} & 1.5 & 0.225 \\
\hline & II & 210 & 158 & 157.5 & 52 & 52.5 & & 0.0 & 0.950 \\
\hline & III & 421 & 318 & 315.8 & 103 & 105.3 & & 0.1 & 0.760 \\
\hline \multirow{3}{*}{$\begin{array}{l}\text { 6-Davis x } \\
\text { Bossier }\end{array}$} & I & 283 & 262 & 265.3 & 21 & 17.68 & \multirow[t]{3}{*}{$15: 1$} & 0.7 & 0.421 \\
\hline & II & 178 & 168 & 166.8 & 10 & 11.12 & & 0.1 & 0.668 \\
\hline & III & 176 & 160 & 165 & 16 & 11 & & 2.4 & 0.100 \\
\hline \multirow{3}{*}{$\begin{array}{l}\text { 7-MG/BR-22 } \\
\text { x Paraná }\end{array}$} & I & 316 & 249 & 237 & 67 & 79 & \multirow[t]{3}{*}{$3: 1$} & 2.4 & 0.100 \\
\hline & II & 172 & 121 & 129 & 51 & 43 & & 2.0 & 0.166 \\
\hline & III & 52 & 35 & 39 & 17 & 13 & & 1.6 & 0.207 \\
\hline \multirow{3}{*}{$\begin{array}{l}\text { 8-MG/BR-22 } \\
\text { x Bossier }\end{array}$} & I & 402 & 299 & 301.5 & 103 & 100.5 & \multirow[t]{3}{*}{$3: 1$} & 0.1 & 0.760 \\
\hline & II & 184 & 127 & 138 & 57 & 46 & & 3.5 & 0.065 \\
\hline & III & 63 & 44 & 47.3 & 19 & 15.8 & & 0.9 & 0.356 \\
\hline \multirow{3}{*}{$\begin{array}{l}\text { 9-MG/BR-22 } \\
\text { x Bragg }\end{array}$} & I & 360 & 348 & 337.5 & 12 & 22.5 & \multirow[t]{3}{*}{$15: 1$} & 5.2 & 0.031 \\
\hline & II & 165 & 152 & 154.6 & 13 & 10.3 & & 2.3 & 0.138 \\
\hline & III & 236 & 215 & 221.3 & 21 & 14.8 & & 2.8 & 0.096 \\
\hline \multirow{2}{*}{$\begin{array}{l}\text { 10-MG/BR-22 } \\
\text { x Davis }\end{array}$} & I & 305 & 236 & 228.8 & 69 & 76.3 & \multirow[t]{2}{*}{$3: 1$} & 0.9 & 0.356 \\
\hline & III & 342 & 266 & 256.5 & 76 & 85.5 & & 1.4 & 0.242 \\
\hline
\end{tabular}

${ }^{1} \mathrm{CJ}$ indicates conventional juvenile flowering type. ${ }^{2} \mathrm{LJ}$ indicates long-juvenile flowering type. Obs.-observed phenotypic ratio. Exp.- expected phenotypic ratio. n. - total number of individuals.

Table IV - Observed and expected phenotypic ratios of number of days to flowering in the $\mathrm{F}_{3}$ populations.

\begin{tabular}{|c|c|c|c|c|c|c|c|c|c|c|}
\hline \multirow[t]{2}{*}{ Cross } & \multirow[t]{2}{*}{ n. } & \multicolumn{2}{|c|}{ Homozygote } & \multicolumn{2}{|c|}{ Segregation } & \multicolumn{2}{|c|}{ LJ } & \multirow[t]{2}{*}{ Ratio } & \multirow[t]{2}{*}{ Chi-Square $\left(\chi^{2}\right)$} & \multirow[t]{2}{*}{ Probability } \\
\hline & & Obs. & Exp. & Obs. & Exp. & Obs. & Exp. & & & \\
\hline 1-Paraná x Bossier & 78 & 31 & 29.3 & 41 & 43.9 & 6 & 4.9 & $8: 7: 1$ & 3.3 & 0.193 \\
\hline 2-Paraná x Bragg & 45 & 12 & 11.3 & 25 & 22.5 & 8 & 11.3 & $1: 2: 1$ & 1.3 & 0.531 \\
\hline 4-Davis x Bragg & 58 & 19 & 14.5 & 28 & 29 & 11 & 14.5 & $1: 2: 1$ & 2.3 & 0.320 \\
\hline 5-Bragg x Bossier & 70 & 17 & 17.5 & 30 & 35 & 23 & 17.5 & $1: 2: 1$ & 2.5 & 0.292 \\
\hline 6-Davis x Bossier & 78 & 32 & 29.3 & 39 & 43.9 & 7 & 4.90 & $8: 7: 1$ & 2.87 & 0.237 \\
\hline 7-MG/BR-22 x Paraná & 88 & 16 & 22 & 48 & 44 & 24 & 22 & $1: 2: 1$ & 2.2 & 0.336 \\
\hline 8-MG/BR-22 x Bossier & 91 & 21 & 22.8 & 47 & 45.5 & 23 & 22.8 & $1: 2: 1$ & 0.2 & 0.911 \\
\hline 9-MG/BR-22 x Bragg & 51 & 21 & 19.1 & 27 & 28.7 & 3 & 3.2 & $8: 7: 1$ & 1.8 & 0.408 \\
\hline 10-MG/BR-22 x Davis & 97 & 19 & 24.3 & 53 & 48.5 & 25 & 24.3 & $1: 2: 1$ & 1.6 & 0.454 \\
\hline
\end{tabular}

LJ - indicates long-juvenile flowering type. Obs.-observed phenotypic ratio. Exp.- expected phenotypic ratio. n. - total number of individuals.

BR-9 (Savana) and Davis cultivars, seeded at $23^{\circ}$ 12' latitude south.

The Paraná cultivar has aa recessive alleles for LJP, but they do not have a pronounced effect under short-day conditions. Similarly, the Bossier cultivar has $b b$ alleles. The segregation of their $\mathrm{F}_{2}$ population resulted in the genotype ratio $9 A-B-, 3 A-b b$ and $3 a a B$ - with conventional flowering (early flowering under short-day conditions) and $1 a a b b$ with late flowering (LJP). There were complementary gene effects or duplicate recessive epistatic effects for LJP under short-day conditions.

The early flowering: LJP ratios of Paraná $\mathrm{x}$ MG/BR-22 (Garimpo) in Experiments I, II and III (Table III) fitted the expected genetic ratio of 3:1 for segregation 
of a single dominant gene controlling the expression of the early flowering trait, or a pair of recessive alleles for LJP expression under short-day conditions. The chi-square tests yielded $p>0.10$ for all the environments (Table III). This genetic hypothesis was confirmed in the assessment of the progenies from $88 \mathrm{~F}_{2}$ plants taken randomly from the population (Table IV). The chi-square test value indicated fit to the expected genetic proportion of 1:2:1 and confirmed the single locus segregation of the cross flowering distribution. The MG/BR-22 (Garimpo), which originated from the Paraná x Bossier cross, has a pair of alleles $(a a)$ in common with the Paraná cultivar so that the $F_{2}$ and $F_{3}$ generations segregate at a single locus $(b b)$.

The $\mathrm{F}_{2}$ population in the Bossier $\mathrm{x}$ MG/BR-22 (Garimpo) cross in Experiment III had a flowering mean intermediate to the parents, but close to the MG/BR-22 (Garimpo) parent (Tables I and II). In Experiment III, $\mathrm{F}_{2}$ segregation ranged from the early parent (Bossier) to later than MG/BR-22 (Garimpo), indicating transgressive segregation for late flowering. Because of the similarity of flowering in the parents, it was not possible to separate the $F_{2}$ generation into distinct classes. However, early flowering dominance over LJP was observed. In Experiment II, a unimodal $\mathrm{F}_{2}$ population distribution was observed (no defined classes), whereas for Experiment III, the groups were not well defined and there was a concentration of early plants. Segregation in Experiment III fitted the 3:1 ratio (conventional flowering:LJP) (Table III). Plant frequency classes were not clearly defined in Experiment II. The result of the MG/BR-22 (Garimpo) x Bossier cross indicated that the LJP characteristic was controlled by a single recessive gene fitting the 3:1 ratio (Table III). Although the $F_{2}$ population in Experiment II had a continuous distribution, there were indications that the expression of the LJP characteristic may have been hidden in some genetic combinations and even in certain photoperiods. As mentioned above, the results of the Paraná x Bossier (fitting the 15:1 ratio) and MG/BR-22 (Garimpo) x Paraná (fitting 3:1 ratio) crosses confirmed the existence of a locus with common alleles and another locus with different alleles in both parents. MG/BR-22 (Garimpo) has two pairs of recessive alleles $(a a b b)$ and Bossier has only one pair of recessive alleles, which confirmed the expected segregation of a single locus (Table III). The segregation observed in the $\mathrm{F}_{2}$ generation was confirmed by analysis of segregation in the $\mathrm{F}_{3}$ plants. Ninety-one plants were randomly selected to obtain $91 \mathrm{~F}_{3}$ families that segregated close to a 1:2:1 ratio for a single locus controlling LJP in this cross (Table IV).

The $\mathrm{F}_{2}$ population of the MG/BR-22 (Garimpo) x Davis cross had a bimodal distribution in the three experiments (Tables I and II). A larger number of conventional flowering plants was observed. It was not possible to categorize the data of Experiment II as the $\mathrm{F}_{2}$ plant frequency distribution was approximately normal, with few individuals in the parental juvenile MG/BR-22 (Garimpo) range. In
Experiment III, 266 plants were classified as early flowering and 76 as having LJP (Table III). These values fitted a 3:1 ratio. The chi-square values of the $\mathrm{F}_{2}$ population (Table III) for Experiments I and III were $0.9(\mathrm{p}=0.356)$, and 1.4 $(p=0.242)$, respectively, indicating that a single locus determined the differences between the parental flowering. Ninety-seven $F_{2}$ derived progenies were tested to confirm this hypothesis. The observed ratio fitted the expected genotype ratio of 1:2:1 for segregation of a pair of recessive genes controlling the expression of the LJP trait under short day conditions (Table IV). Tisseli (1981) studied the inheritance of soybean flowering under short-day conditions and found that the Davis cultivar had a gene for the juvenile period. Kiihl and Garcia (1989) suggested that the Davis cultivar had the same gene for LJP as the Paraná cultivar, probably inherited from Ogden, a parent common to both of these cultivars.

The $\mathrm{F}_{2}$ population in the MG/BR-22 (Garimpo) $\mathrm{x}$ Bragg cross in the three environments showed no transgressive segregation and had a clear bimodal distribution with a greater concentration of early-flowering $\mathrm{F}_{2}$ individuals (Tables I and II). The absence of transgressive, late-flowering plants in MG/BR-22 (Garimpo) may exist because Bragg did not contribute any genes affecting this trait. As already mentioned, the Bragg cultivar has conventional flowering when sown under short-day conditions. The segregation of the $F_{2}$ population fitted a 15:1 ratio (conventional flowering:LJP) in Experiment II and III (Table III). This phenotypic ratio indicated the presence of two pairs of recessive alleles controlling the LJP trait in this cross. Analysis of the results of the MG/BR-22 (Garimpo) $\mathrm{x}$ Bragg cross showed the segregation of two genes with independent distribution, with early flowering determined by genotypes which have at least one dominant allele; LJP occurred only when the genotype was homozygous for recessive alleles of the two loci. This suggested a case of duplicate dominant epistasis (Ramalho et al., 1994). The results from the $F_{2}$ populations were confirmed by the $F_{2}$ progeny test in which $51 \mathrm{~F}_{3}$ families were assessed. The frequency distributions agreed with the expected genetic ratio of 9:6:1 for the segregation of two loci (Table IV). These results confirmed the genetic hypothesis that the LJP characteristic in the MG/BR-22 (Garimpo) cultivar is controlled by two pairs of recessive alleles ( $a a b b)$.

The Bragg x Paraná cross in the $\mathrm{F}_{2}$ population fitted the expected genetic hypotesis of Mendelian monogenic segregation (3:1 ratio) (Tables II and III). The flowering distribution in the $F_{2}$ generation was intermediate to that of the parents in Experiment II. The segregation of the $\mathrm{F}_{2}$ population in Experiment III was multimodal and transgressive. Dominance of early over late flowering was observed in the three experiments. In the $\mathrm{F}_{1}$ generation there was also dominance of early flowering over late flowering. In Experiment III, the $\mathrm{F}_{2}$ generation showed transgressive segregation for later flowering. The flowering category in 
Experiments II and III fitted the 3:1 expected ratio for a single locus controlling flowering (Table III). Since for LJP to be expressed two recessive loci ( $a a b b)$ must be present, no such gene differences were apparently present in the $F_{2}$ population of Paraná $x$ Bragg. Transgressive segregation in the $\mathrm{F}_{2}$ population in Experiment III may have resulted from modifying genes which possibly recombined with the $a a$ gene from the Paraná cultivar and only acted when the photoperiod and temperature conditions were not critical or limiting to the manifestation of the transgressive late flowering trait. There was a good agreement in the observed $12: 25: 8$ ratio with the expected genetic ratio of $1: 2: 1$. Thus, the differences in the time to flowering between the two parents were attributable to the action of a single major gene (Table IV).

The Bragg cultivar is considered to behave classically for photoperiod, flowering early when cultivated under short-day conditions. The Paraná cultivar has a major gene in its genotype which, when combined with other genes, may manifest a LJP in early sowings (Kiihl and Garcia, 1989 and Miranda et al., 1990).

The $\mathrm{F}_{2}$ plants of the Bragg $\mathrm{x}$ Bossier cross of Experiments I and II followed a typically bimodal model with no transgressive segregation for late flowering (Bossier cultivar). In Experiment III, there was a multimodal distribution with visible transgressive segregation for late flowering. This trend may reflect the expression of the Bossier LJP gene, together with modifying genes that manifest themselves under certain photoperiod and temperature conditions in mid-October planting. The observed in Experiments I, II and III, fitted the Mendelian single locus hypothesis (Table III). Analysis of the $\mathrm{F}_{3}$ segregation (Table IV) confirmed the segregation results obtained in the $\mathrm{F}_{2}$ population. The frequency ratio fitted the expected ratio 1:2:1 ratio, showing that the two parents diverged in flowering at an allele of a single major locus. There was a certain coincidence in the parents flowering in all of the experiments for of the Paraná $\mathrm{x}$ Davis cross, as well as a normal frequency distribution for flowering (Tables I and II). This made categorizing the data difficult and it was not possible to identify a splitting point. The results indicate that the Paraná and Davis cultivars have a major gene in common for late flowering under short-day conditions. The $\mathrm{F}_{2}$ segregation ranged observed in Experiment III may be the result of modifier genes. This hypothesis was confirmed when the data from crosses in which Davis and Paraná were combined with other genotypes and were compared and showed a fairly similar frequency distribution and segregation.

Toledo et al $(1993,1994)$ studied the genetic control of flowering in soybean genotypes under three photoperiods. Four soybean parents, including three with conventional type of response to photoperiod (BR85-29009, FT-2 and BR-13) and one long juvenile trait carrier (Oc-8), were crossed in all combinations, including reciprocals.
Significant dominance, epistasis and genotype $\mathrm{x}$ enviromental effects were detected. Genes controlling classical and long juvenility combined freely. Intermediate responses between the typical classical and typical long juveniles were also observed in all cases. Such responses are only possible through the recombination of various genes of a single system.

The flowering frequency distributions of the $\mathrm{F}_{2}$ plants of the crosses between Bossier $\mathrm{x}$ Davis, and Paraná $\mathrm{x}$ Bossier were very similar (Tables II and III) indicating that the genetic control of LJP may be conditioned by the recombination of pairs of recessive alleles (Table III). This hypothesis was confirmed by the $\mathrm{F}_{2}$ progeny test $\left(78 \mathrm{~F}_{3}\right.$ families). The ratio fitted the expected model for segregation of two loci (9:6:1) (Table IV). The results showed that the Davis cultivar had the same LJP gene in its genetic constitution as the Paraná cultivar ( $a a$ ), but may differ in modifying genes. The inheritance of LJP, conditioned by two recessive genes, is a typical case of duplicate recessive epistasis.

The distribution of the $F_{2}$ plants was very similar to that of the corresponding generation in the Bragg x Paraná cross (Tables I and II). The relatively low chi-square values (Table III) confirmed the high probability of a pair of genes determining the flowering differences between the Bragg and Davis parents. This hypothesis was confirmed by the results of the progeny test of the $\mathrm{F}_{2}$ population (Table IV). The ratio observed fitted the expected genetic model for single locus segregation (1:2:1).

Bragg is considered to respond classically to photoperiod, flowering early when planted under short-day conditions. Tisseli (1981) reported the presence of a major gene in the Davis cultivar, which, when recombined with other genes, may express the LJP characteristic. The results described above support the hypothesis that the Davis cultivar has the same major gene for LJP as the Paraná cultivar.

The $F_{1}$ populations from all the crosses studied had a mean time to flowering similar to the early parent, indicating that early flowering is dominant over late flowering. The LJP characteristic is conditioned by the effect of two recessive gene loci. Genotypes with a single pair of recessive alleles do not show the LJP characteristic in early sowings. The Paraná cultivar has one pair of recessive alleles, and its genotypic constitution is $a a B B$. The Davis cultivar has the same genetic constitution for the control of flowering as the Paraná cultivar. The Bossier cultivar contributes a pair of recessive alleles different from those of Paraná, and its genotypic constitution is $A A b b$. The LJP characteristic in MG/BR-22 (Garimpo) is controlled by the combination of two recessive genes, a case of a double recessive epistatic gene action. Its genotypic constitution is aabb. The Bragg cultivar did not have LJP genes and is represented as $A A B B$. Maternal effects did not influence the genetic expression of flowering for these crosses. The small range of flowering in the greenhouse $F_{2}$ population indi- 
cated that this environment was not suitable for the expressing of genetic variability in the population. Early sowing in the field from the end of September to the middle of October was an effective strategy to allow selection of plants with LJP.

\section{References}

Easton FM (1924) Assimilation-respiration balance as related to length of day reactions of soybeans. Botan. Gazette 77:311321.

Bonato ER, Vello NA (1999) E6 a dominant gene conditioning early flowering and maturity in soybeans. Genetics and Molecular Biology 22(2):229-232

Carpentieri-Pípolo V, Almeida LA, Kiihl RAS, Rosolem CA (2000) Inheritance of long juvenile period under short day conditions for the BR80-6778 soybean (Glycine max (L.) Merrill) line. Euphytica 112(2):203-209.

Hartwig EE and Kiihl RAS (1979) Identification and utilization of delayed flowering character in soybeans for short-day conditions. Field Crops Res 2:145-151.

Kiihl RAS (1976) Inheritance studies of two characters in soybean (Glycine max (L.) Merrill); I. Resistance to soybean mosaic virus; II. Late flowering under short-day conditions. Doctoral thesis, Mississippi State University, Mississippi.

Kiihl RAS and Garcia A (1989) The use of the long-juvenile trait in breeding soybean cultivars. In: Pascale AJ (ed) Proceedings, World Soybean Research Conference IV. Buenos Aires. Asociacion Argentina de la Soja, Argentina, pp 994-1000.

Major DJ, Johnson DR, Tanner JW and Anderson IC (1975) Effects of daylength and temperature on soybean development. Crop Sci 15:174-179.

Miranda MAC, Mascarenhas HAA, Pereira JCVA, Gallo PB, Diehl SRL and Pizan NR (1990) Soja: avaliação de linhagens com período juvenil longo e obtenção do cultivar IAC15. Bragantia 49:253-268.

Neumaier N and James AT (1993) Exploiting the long juvenile trait to improve adaptation of soybeans to the tropics. Food Legume Newsl 18:12-14.

Oliveira ACBde, Sedyama CS and Cruz CD (1999) Selection for late flowering in soybean (Glycine $\max \mathrm{L}$. Merrill) $\mathrm{F}_{2}$ populations cultivated under short day conditions Genet Mol Biol 22(2):243-247
Parker MW and Borthwick HA (1950) Influence of light on plant growth. Ann Rev f Plant Physiol 1:43-58.

Ramalho MAP, Santos JB and Pinto CABP (1994) Genética na Agropecuária. Globo, São Paulo.

Ray JD, Hinson K, Mankono EB and Malo FM (1995) Genetic control of a long-juvenile trait in soybean. Crop Sci 35:1001-1006.

Roessing, A.C. and Guedes, L.C.A. (1993). Aspectos econômicos do complexo soja: sua participação na economia brasileira: evolução na região do Brasil Central. In: Arantes NE and Souza PIM (eds) Cultura da Soja nos Cerrados. Potafós, Piracicaba, pp 1-104.

Shibles R, Anderson JC and Gibson AH, (1976) Soybean. In: Evans, LT (ed) Crop Physiology: Some Case Histories. Cambridge University Press, London, pp 151-189.

Snedecor GWW and Cochchran WG (1980) Statistical Methods. Iowa State University, Ames.

Summerfield RJ, Bunting AH and Roberts EH (1975) Use of controlled environmental facilities as an adjunct to field research on potentially tropic-adapted rain-legumes. Phyto New 11:36-41.

Spehar CR, Monteiro PMF de O and Zuffo NL (1993) Melhoramento Genético da soja na região centro oeste. In: Arantes NE, and Souza PIM (eds) Cultura da Soja nos cerrados. Potafós, Piracicaba, pp 229-251.

Toledo JFF and Kiihl RAS (1982 a) Análise do modelo genético envolvido no controle de dias para o floresciemtno em soja . Pesquisa Agropecuária Brasileira 17:623-631.

Toledo JFF and Kiihl RAS (1982 b) Método de análise dialélica do modelo genético em controle das características dias para a floração e número de folhas trifolioladas em soja. Pesquisa Agropecuária Brasileira 17:745-755.

Toledo JF, Oliveira MF, Tsutida AC and Kiihl RA (1993) Genetic Analysis of grouth of determinate soybean genotypes under three photoperiods. Rev Bras Genet 16(3):713-784.

Toledo JF, Thriller C, Donato LT, Oliveira MF de and Tsutida AC (1994) Genetic control of flowering in determinate soybean genotypes under diverse photoperiods. Rev Bras Genet 17(2):187-195.

Tisselli Jr. O (1981) Inheritance study of the long-juvenile characteristics in soybeans under long-and sort-day conditions. Doctoral thesis, Mississippi State University, Mississippi.

Vargas AT (1996) Estudo genético em variantes naturais de cultivares de soja (Glycine max (L.) Merrill) para florescimento tardio. Master's thesis, Universidade Estadual de Londrina, Londrina. 